\title{
PELAYANAN PUBLIK BAGI PEMENUHAN HAK-HAK DISABILITAS DI KOTA YOGYAKARTA
}

\author{
Sugi Rahayu dan Utami Dewi \\ sugirahayu@uny.ac.id dan utami.dewi@uny.ac.id
}

This research aims to analyze public policy and service implemented to people with disability. This research is important and interesting because of lack of government's attention in fulfilling the rights of people with disability. This qualitative descriptive research shows that Yogyakarta City Government has made serious effort to give friendly public service to people with disability. Education Office has launched inclusive education program to give them opportunity to access equal and indiscriminative education. Furthermore, the presence of Blind Corner in Arpusda shows City Government's effort to equalize them. In term of health, there is Jamkesmas special for people with disability, even though in its practice it is still rarely used by the group. In term of social, Social, Labor, and Transmigration Office has given some aids and capital mentoring every month to families with disability and employed them. The presence of Transjogja and special vehicle for them is effort to equalize them in society. However, programs to make friendly service have not been optimum because of the obstacles in its implementation. Human resource barrier, budget and people's stigma toward people with disability make fair public service implementation is less effective.

Keywords: public service, disability, Yogyakarta City.

Menjadi difabel ditengah masyarakat yang menganut paham 'normalisme', paham pemuja kenormalan, dimana semua sarana umum yang ada didesain khusus untuk 'orang normal' tanpa adanya fasilitas bagi difabel adalah sangat sulit. Dipandang kasihan atau tidak dianggap dalam bermasyarakat adalah sesuatu yang acap kali kita lihat dilingkungan difabel. Bahkan pusat rehabilitasi sekalipun diciptakan menjadikan mereka 'berbeda' dengan orang lain. Terlebih dengan sebutan 'rehabilitasi' difabel disetarakan dengan para pecandu narkotika dan obat obatan terlarang seolah mengalami kecacatan adalah sebuah penyakit yang harus segera diobati. Akan tetapi benarkah menjadi difabel adalah setara dengan digerogoti penyakit? Seseorang yang memang diciptakan dengan satu 'perbedaan' oleh Sang Pencipta mungkin tidaklah membutuhkan rehabilitasi melainkan lebih membutuhkan persamaan derajat dan pengakuan dari lingkungannya.

Jumlah difabel di Indonesia pada tahun 2007 diprediksi sekitar 7,8 juta jiwa (Suharto, Edi, 2010). Sebuah angka yang sebenarnya relatif kecil dibandingkan jumlah penduduk Indonesia pada waktu itu berjumlah sekitar 220 juta jiwa. Walaupun demikian selayaknya semangat pelayanan tidak dipengaruhi jumlah besar atau kecilnya pengguna layanan. Para difabel juga merupakan warga negara Republik Indonesia yang dalam Undang-Undang Dasar 1945 dijamin untuk memiliki kedudukan, hak, kewajiban, dan peran yang sama dengan warga negara lainnya. Dalam rangka mewujudkan pembangunan nasional yang bertujuan 
mewujudkan masyarakat yang adil dan makmur berdasarkan Pancasila dan Undang-Undang Dasar 1945. Untuk itu Pemerintah hendaknya memberikan perhatian yang cukup kepada para difabel tersebut. Termasuk dalam hal aksesibilitas pelayanan publik.

Kenyataan di lapangan menunjukkan kondisi sebaliknya, minimnya sarana pelayanan sosial dan kesehatan serta pelayanan lainnya yang dibutuhkan oleh para difabel, termasuk aksesibilitas terhadap pelayanan umum yang dapat mempermudah kehidupan difabel dimana sebagian besar hambatan aksesibilitas tersebut berupa hambatan arsitektural, membuat difabel kehilangan haknya dalam mendapatkan pelayanan yang baik.

Dalam hal aksesibilitas, ketersediaan sarana dan prasarana ramah difabel saat ini masih sangat terbatas di Indonesia pada umumnya dan Yogyakarta khususnya. Aksesibilitas difabel yang dijanjikan pemerintah dalam UU No 4 th 1997 pada prakteknya tetap saja belum mempermudah akses pergerakan mereka. Beberapa sarana umum yang dibangun dengan mempertimbangkan difabel bahkan pada pelaksanaannya masih saja menyulitkan mereka. Tempat ibadahpun bahkan masih belum ramah terhadap keberadaan para difabel.

Selain UU No 4/1997 yang khusus mengatur pemenuhan hak difabel, pemerintah juga telah mengeluarkan dan mengimplementasikan Undang-Undang Undang Nomor 25 Tahun 2009 tentang Pelayanan Publik. UU NO 25/2009 tersebut bertujuan untuk memberikan kejelasan dan pengaturan mengenai pelayanan publik bagi seluruh warga negara termasuk penduduk yang berkebutuhan khusus yaitu kaum difabel. Undang-Undang ini secara tegas menyatakan bahwa pelayanan publik memiliki beberapa asas yang mengamanahkan kemudahan aksesibilitas kepada difabel. Namun demikian, tampaknya kehadiran UU tersebut belum mapu menjadi pegangan bagi penyelenggara pemerintahan untuk memberikan pelayanan publik tanpa diskriminasi. Para difabel masih menemui hambatan fisik dan psikologis dalam memperoleh hak-hak mereka.

Konsep pelayanan publik memiliki makna yang tidak jauh berbeda dengan konsep pelayanan umum atau pelayanan masyarakat. Oleh karena itu, penggunaan ketiga istilah tersebut saling dipertukarkan. Pelayanan publik menurut Undang-Undang Nomor 25 Tahun 2009 adalah kegiatan atau rangkaian kegiatan dalam rangka pemenuhan kebutuhan pelayanan sesuai dengan peraturan perundang-undangan bagi setiap warga negara dan penduduk atas barang, jasa, dan/atau pelayanan administratif yang disediakan oleh penyelenggara pelayanan publik. Pelayanan berfungsi sebagai sebuah sistem yang menyediakan apa yang dibutuhkan oleh masyarakat.

Keputusan Menteri Negara Pendayagunaan Aparatur Negara (Meneg PAN) Nomor 63/KEP/M.PAN/7/2003, memberikan pengertian pelayanan publik yaitu segala kegiatan 
pelayanan yang dilaksanakan oleh penyelenggara pelayanan publik sebagai upaya pemenuhan kebutuhan penerima pelayanan maupun pelaksanaan ketentuan peraturan perundangundangan.

Fungsi pelayanan publik adalah salah satu fungsi fundamental yang harus diemban pemerintah baik di tingkat pusat maupun di daerah. Fungsi ini juga diemban oleh BUMN/BUMD dalam memberikan dan menyediakan layanan jasa dan atau barang publik. Dalam konsep pelayanan, dikenal dua jenis pelaku pelayanan, yaitu penyedia layanan dan penerima layanan. Penyedia layanan atau service provider (Barata, 2003: 11) adalah pihak yang dapat memberikan suatu layanan tertentu kepada konsumen, baik berupa layanan dalam bentuk penyediaan da penyerahan barang (goods) atau jasa-jasa (services). Penerima layanan atau service receiver adalah pelanggan (customer) atau konsumen (consumer) yang menerima layanan dari para penyedia layanan.

Pelayanan publik seharusnya memperhatikan asas-asas keadilan dan non-diskriminatif, seperti tercantum dalam UU no 25/2009 tentang Pelayanan Publik. Menurut UU tersebut, pelayanan publik dikatakan baik jika memenuhi beberapa asas-asas kepentingan umum, kepastian hukum, kesamaan hak, keseimbangan hak dan kewajiban, keprofesionalan, partisipatif, persamaan perlakuakn/tindak diskriminatif, keterbukaan, akuntabilitas, fasilitas dan perlakukan khusus bagi kelompok rentan, ketepatan waktu, serta kecepatan kemudahan dan keterjangkauan. Dengan demikian, jelas bahwa seharusnya pelayanan publik tetap memperhatikan keadilan dan ramah terhadap masyarakat berkebutuhan khusus seperti kaum difabel sebagai salah satu kelompok masyarakat rentan selain wanita dan anak-anak.

Difabel menurut Undang-Undang No 4 tahun 1997 tentang Penyandang Cacat, adalah setiap orang yang mempunyai kelainan fisik dan/atau mental, yang dapat mengganggu atau merupakan rintangan dan hambatan baginya untuk melakukan aktivitas secara selayaknya, yang terdiri dari (a) penyandang cacat fisik, (b) penyandang cacat mental, dan (c) penyandang cacat fisik dan mental. Dalam Declaration of The Rights of Disabled Persons (1975) disebutkan bahwa seorang difabel adalah seseorang yang tidak dapat menjamin keseluruhan atau sebagian kebutuhan dirinya sendiri sesuai dengan kebutuhan manusia pada normalnya dan/atau kehidupan sosialnya sebagai akibat dari kekurangan fisik dan atau kemampuan mentalnya.

Difabel bukan hanya merupakan orang-orang penyandang cacat sejak lahir melainkan juga korban bencana alam atau perang yang mendapatkan kecacatan ditengah-tengah hidupnya maupun para penderita penyakit yang mengalami gangguan melakukan aktivitas secara selayaknya baik gangguan fisik maupun mental. Beberapa jenis gangguan yang menyebabkan 
tergolongnya seseorang menjadi difabel adalah sebagai berikut : tuna netra (buta), tuna rungu (tuli), tuna wicara (bisu), tuna daksa (cacat tubuh), tuna grahita (cacat mental) dan tuna ganda ( komplikasi antara dua atau lebih bentuk kecacatan).

Undang-undang No. 4 tahun 1997 menegaskan bahwa difabel merupakan bagian masyarakat Indonesia yang juga memiliki kedudukan, hak, kewajiban, dan peran yang sama. Mereka juga mempunyai hak dan kesempatan yang sama dalam segala aspek kehidupan dan penghidupan. Pada pasal 6 dijelaskan bahwa setiap difabel berhak memperoleh: (a) pendidikan pada semua satuan, jalur, jenis, dan jenjang pendidikan; (b) pekerjaan dan penghidupan yang layak sesuai jenis dan derajat kecacatan , pendidikan, dan kemampuannya; (c) perlakuan yang sama untuk berperan dalam pembangunan dan menikmati hasil-hasilnya; (d) aksesibilitas dalam rangka kemandiriannya; (e) rehabilitasi, bantuan sosial, dan pemeliharaan taraf kesejahteraan sosial; dan (f) hak yang sama untuk menumbuhkembangkan bakat, kemampuan, dan kehidupan sosialnya, terutama bagi difabel anak dalam lingkungan keluarga dan masyarakat.

Pada prakteknya difabel memang diberikan hak-hak tersebut. Hak atas pendidikan, hak atas pekerjaan sesuai kecacatan, aksesibilitas, dan yang lainnya. Akan tetapi hak tersebut semata mata difasilitasi oleh pemerintah tanpa ada pengarahan kepada difabel dan masyarakat keluarga penyandang cacat tersebut. Contohnya dalam praktek pendidikan yang diberikan pemerintah berupa SLB. Pemerintah membangun SLB walaupun dengan jumlah yang belum memadai. Akan tetapi minimnya sosialisasi dari pemerintah tentang pendidikan difabel ini menciptakan pengekangan hak tersebut dalam keluarga para penyandang cacat.

Anggapan tentang kecacatan yang merupakan sebuah penyakit yang tidak dapat lagi disembuhkan membuat keluarga keluarga difabel berputus asa dan beranggapan bahwa mereka tidaklah membutuhkan pendidikan. Padahal difabel sama halnya dengan orang lain. Hanya keterbatasan fisiklah (dan mental bagi penyandang tuna grahita) yang membuat mereka 'berbeda' dari orang lain. Dan perbedaan tersebut pada dasarnya bukan alasan mereka mempunyai Hak Asasi yang berbeda dari olang lain. Lain lagi kasusnya pada hak mendapatkan pekerjaan yang layak bagi difabel yang pada intinya tetap saja perhatian masyarakat dan pemerintahlah yang dituntut lebih dibanding apa yang masyarakat punya pada saat ini.

Selain UU No. 4/1997, pemerintah juga telah mengeluarkan Peraturan Pemerintah Nomor 43 Tahun 1998 tentang Upaya Peningkatan Kesejahteraan Sosial Penyandang Cacat. Pengaturan aksesibilitas pelayanan lebih lanjut bagi difabel secara lebih jelas dan gamblang diatur dalam Peraturan Pemerintah Nomor 43 Tahun 1998 tentang Upaya Peningkatan Kesejahteraan Sosial Penyandang Cacat. Difabel dalam PP ini dijamin kesamaan kesempatan 
dalam hak, kewajiban dan perannya sesuai dengan kemampuannya dalam kehidupan berbangsa dan bernegara. Agar difabel dapat berperan serta secaramaksimal aksesibilitas bagi difabel dijamin.

Kebijakan terbaru berkaitan dengan difabel khususnya di Propinsi Daerah Istimewa Yogyakarta adalah Peraturan Daerah No 4 tahun 2012 tentang Perlindungan dan Pemenuhan Hak-Hak Penyandang Disabilitas. Perda ini mencakup tentang penerapan pendidikan inklusi, pekerjaan kepada difabel (adanya penghargaan kepada perusahaan yang memberikan pekerjaan kepada difabel), kebijakan jaminan pembiayaan kesehatan daerah kepada difabel serta beberapa kebijakan layanan yang sudah mulai berpihak kepada difabel. Pasal 3 perda ini menegaskan bahwa Pemerintah Daerah Propinsi DIY menjamin hak-hak kaum difabel meliputi hak dalam bidang pendidikan, ketenagakerjaan, kesehatan, sosial, seni, budaya, olah raga, politik, hukum, penanggulangan bencana, tempat tinggal, dan aksesibilitas.

\section{Metode Penelitian}

Penelitian ini termasuk dalam penelitian kualitatif, dimana peneliti bertujuan untuk mendeskripsikan dan menganalisa penerapan pelayanan publik berkaityang diberikan kepada difabel baik pelayanan fisik maupun non-fisik. Penelitian ini difokuskan di Kota Yogyakarta dengan beberapa pertimbangan. Pertama, Kota Yogyakarta merupakan salah satu pusat pendidikan di Daerah Istimewa Yogyakarta yang terkenal sebagai Kota Pendidikan. Kota Yogyakarta merupakan kota pendidikan, dimana berbagai perguruan tinggi, ilmuwan, dan aktivis pemerhati masalah-masalah sosial kemasyarakatan berada dan berani memberikan penilaian kritis terhadap sebuah kebijakan pemerintah khususnya bagi difabel. Kedua, Pemerintah Kota Yogyakarta termasuk dalam kategori the best dalam memberikan pelayanan kepada publik. Peneliti akan menganalisis apakah pelayanan yang baik tersebut juga sudah diterapkan bagi kaum berkebutuhan khusus. Ketiga, pertimbangan praktis, yaitu kemudahan akses bagi peneliti.

Jenis data yang dibutuhkan dalam penelitian ini meliputi data primer dan data sekunder. Data tersebut dikumpulkan dengan teknik wawancara dan dokumentasi. Teknik analisa data yang digunakan dalam penelitian ini adalah teknik analisa kualitatif. Proses analisa data dimulai dengan menelaah seluruh data yang telah diperoleh dari berbagai sumber. Kemudian dilakukan reduksi data dengan jalan membuat abstraksi. Langkah selanjutnya adalah menyusun data dalam satuan-satuan. Satuan-satuan itu kemudian dikategorisasikan pada langkah berikutnya. Pengkategorian itu dilakukan sambil membuat koding. Tahap terakhir adalah mengadakan pemeriksaan keabsahan data. Setelah tahap ini selesai, maka baru dilakukan 
penafsiran data (Moleong, 1990). Sehingga tahap-tahap dalam analisa data kualitatif meliputi: pemrosesan satuan data, reduksi data, pengkategorisasian data termasuk pemeriksaan keabsahan data, dan penafsiran data.

Terakhir, peneliti menggunakan teknik triangulasi yaitu melalui tiga tahapan pengecekan: Pertama, triangulasi sumber data, yaitu membandingkan data yang diperoleh melalui teknik wawancara dengan data hasil observasi dan survei. Kedua, melakukan peer review untuk mengetahui pendapat para peneliti dan pakar lain yang melakukan penelitian serupa. Ketiga, peneliti akan melakukan triangulasi teori, yaitu membandingkan data empiris dengan kajian teoritis yang telah berkembang dan diakui kebenarannya.

\section{Hasil Penelitian dan Pembahasan}

Setiap warga negara memiliki hak untuk mendapatkan pelayanan yang sama dari pemerintah, tak terkecuali mereka yang berkebutuhan khusus atau kaum difabel. Kaum difabel tidak hanya menjadi urusan Dinas Sosial tetapi mereka juga membutuhkan pelayanan yang adil dalam bidang pendidikan, kesehatan, aksesibilitas fisik pada bangunan hingga hak berpolitik. Oleh karena itu, penelitian ini menganalisis bagaimana pemberian pelayanan diberikan oleh Pemerintah Kota Yogyakarta dalam memenuhi kebutuhan pendidikan, kesehatan dan interaksi sosial lainnya.

Jumlah difabel di Propinsi Daerah Istimewa Yogyakarta berdasarkan data Dinas Sosial tahun 2011 adalah 35. 264 orang, dan untuk Kota Yogyakarta sendiri berjumlah 3.353 orang atau sekitar 9. $51 \%$ dari total jumlah kelompok berkebutuhan khusus di DIY. Berdasrakan jenis kelamin, penyandang cacat di Kota Yogyakarta adalah seperti terlihat dalam tabel 1 berikut ini.

Tabel 1. Jumlah Penyandang Cacat di Kota Yogyakarta Tahun 2011

\begin{tabular}{|l|l|r|r|}
\hline NO & \multicolumn{1}{|c|}{ KETERANGAN } & JUMLAH & \multicolumn{2}{c|}{} \\
\hline 1 & Laki-laki & 1.836 & 54,76 \\
\hline 2 & Perempuan & 1.517 & 45,24 \\
\hline \multicolumn{2}{|c|}{ JUMLAH } & 3.353 & 100,00 \\
\hline
\end{tabular}

Ada beberapa pelayanan bagi para difabel di Yogyakarta, yaitu sebagai berikut.

\section{Pelayanan Pendidikan}




\section{Pendidikan Inklusi}

Hak setiap warga negara adalah mendapatkan pendidikan yang layak dan tanpa diskriminasi. Hak pendidikan ini juga berlaku kepada orang berkebutuhan khusus atau penyandang cacat atau yang biasa disebut difabel (different ability). UU No. 4 Tahun 1997 tentang Penyandang Cacat dan UU No. 20 Tahun 2003 tentang Sistem Pendidikan Nasional menekankan hak setiap warga negara untuk memperolah pendidikan sesuai dengan jenjang, jalur, satuan, bakat, minat, dan kemampuannya tanpa diskriminasi. Dengan kata lain, dalam sektor pendidikan formal seharusnya tidak ada lagi sekat sosial yang membedakan para difabel dengan masyarakat umum. Orang tua bisa mendaftarkan anak difabel mereka ke sekolah umum. UU No. 4 Tahun 1997 pasal 12 mewajibkan lembaga-lembaga pendidikan umum menerima para difabel sebagai siswa. Kewajiban seperti inilah yang disebut sebagai model inklusi.

Model inklusi adalah peluang bagi terjadinya interaksi sosial antara para difabel dan masyarakat pada umumnya. Sejak disyahkannya Peraturan Walikota Yogyakarta No : 47 / 2008 tentang Penyelenggaraan Pendidikan Inklusi di kota Yogyakarta, Pendidikan Inklusi mulai di laksanakan secara intensif. Dinas Pendidikan Kota Yogyakarta memaknai Perwal tersebut sebagai dasar bahwa untuk menyusun regulasi yang memudahkan akses bagi Anak Berkebutuhan Khusus (ABK) untuk dapat bersekolah di sekolah umum bersama sama dengan anak normal lainnya. Setiap anak usia sekolah wajib diterima di sekolah umum, selama sekolah yang bersangkutan mempunyai kemampuan untuk melayaninya. Sekolah Inklusi memberikan peluang bagi siswa dengan setiap perbedaannya untuk dapat berhasil dalam belajar di sekolah reguler (umum). Sehingga sekolah inklusi mensyaratkan adanya keterbukaan, keadilan, tanpa diskriminasi, ramah dan terbuka dengan mengedepankan tindakan menghargai dan merangkul perbedaan yang ada pada siswa /ABK. Hal ini berbeda dengan kurun waktu sebelumnya, pendidikan bagi ABK hanya dapat dilayani oleh Sekolah Luar Biasa (SLB).

Keputusan Kepala Dinas Pendidikan Kota Yogyakarta No : 0063/2009 tentang Petunjuk Teknis Penyelenggaraan Pendidikan Inklusif di Kota Yogyakarta, mempunyai implikasi pada kebijakan pemberian SK bagi sekolah yang mempunyai anak didik berkebutuhan khusus menjadi sekolah penyelenggara Pendidikan Inklusi (SPPI). Tercatat sebagi sekolah penyelenggara pendidikan inklusi saat ini 21 sekolah mulai jenjang PAUD/TK, SD, SMP, SMA dan SMK. Kebijakan ini gayung bersambut dengan semangat yang tinggi para Guru Pendamping Khusus (GPK) dan Guru Reguler yang mempunyai anak didik berkebutuhan khusus (ABK). Mereka layak mendapat apresiasi, karena beban kerja ekstra untuk memodifikasi kurikulum, metode dan proses pembelajaran, mampu dilaksanakan tanpa 
mengeluh. Kesulitan dalam mendidik ABK menjadi tantangan dan menjadi bahan kajian dalam pertemuan konferensi kasus pada Forum Guru Pendamping Khusus (GPK), hal ini berdampak pula pada peningkatan mutu dan jiwa korps GPK Kota Yogya.

Tahun 2011-2012 kegiatan semakin berkembang, diklat-diklat teknis peningkatan mutu guru inklusi sudah terlaksana, misalnya: TOT Pendidikan Inklusif kerjasama Hellen Keller International/HKI- Dikpora DIY dengan materi inti asesmen siswa dan modifikasi kurikulum. Stake Holder yang peduli semakin banyak yaitu adanya Resource Centre, Forum Sekolah Penyelenggara Pendidikan Inklusi (SPPI) Kota Yogyakarta (SPPI), dan Forum Guru Pendamping Khusus (GPK) Kota, sebagai wadah para "konsultan intern" sekolah inklusi. Kerjasama Dinas Pendidikan dengan UNY, UGM dan SLBN 2 Yogyakarta diharapkan makin meningkatkan kualitas Pendidikan Inklusi di Kota Yogyakarta. Bhakan Pemerintah Kota Yogyakarta telah meraih Inclusive Education Award tahun 2012 ini.

Inclusive Education Award merupakan pengakuan pemerintah pusat terhadap kemajuan Pendidikan Inklusi untuk Kota Yogya yang sudah dievaluasi selama 3 bulan. Dengan penghargaan tersebut Pemerintah Kota Yogyakarta semakin berbenah agar anak - anak berkebutuhan khusus (ABK) yang selama ini terpinggirkan, akan dapat mengakses pendidikan yang lebih layak sebagaimana anak anak bangsa yang lain.

Sayangnya, belum banyak difabel yang mengakses sekolah model inklusi akibat minimnya informasi mengenai sekolah inklusi, ketiadaan biaya, infrastruktur yang kurang mendukung serta kondisi kultural budaya yang cenderung menyembunyikan“ anak difabel karena dianggap sebagai aib. Selain itu terdapat beberpa masalah berkaitan dengan penyelenggaraan sekolah inklusi ini. Sekolah-sekolah inklusi yang dibuka tidak dibarengi dengan penyiapan guru-guru untuk menangani anak-anak berkebutuhan khusus. Jumlah Guru Pendamping Khusus yang ada sampai saat ini adalah 75 orang. Jumlah ini jauh dari idealnya. Disamping itu, penyediaan sarana belajar yang aksesibel seperti gedung sekolah dan media belajar yang aksesibel juga belum maksimal dalam pengembangan dan penyelenggaraan sekolah inklusi di Kota Yogyakarta (Wawacara dengan Bp. Agus Widodo, Dinas Pendidikan Kota Yogyakarta).

\section{Sekolah Luar Biasa (SLB)}

Selain sekolah inklusi, untuk penyediaan kebutuhan pendidikan bagi difabel, Sekolah Luar Biasa merupakan pilihan. Berbeda dengan sekolah inklusi yang tidak membedakan perlakuan antara siswa biasa dan berkebutuhan khusus, Sekolah Luar Biasa hanya menampung mereka yang memiliki keterbatasan fisik atau mental. Saat ini di Kota Yogyakarta terdapat 7 SLB yang merupakan kewenangan dari Propinsi Daerah Istimewa Yogyakarta. Dinas 
Pendidikan Pemerintah Kota Yogyakarta tidak mempunyai tugas dan wewenang dalam mengurusi SLB ini.

Di Daerah Istimewa Yogyakarta terdapat 62 Sekolah Luar Biasa negeri dan swasta yang dapat dibedakan berdasarkan tipenya yakninya: (a) SLB tipe A : Diperuntukkan bagi Tuna Netra, (b) SLB tipe B : Diperuntukkan bagi Tuna rungu dan tuna wicara, (c) SLB tipe C : Diperuntukkan bagi tuna grahita, dan (d) SLB tipe D: Diperuntukkan bagi tuna daksa.

Beberapa hal yang ditekankan dalam penyelenggaraan SLB sebagai lembaga pendidikan Indonesia adalah: (a) Tunanetra: membaca dan menulis braille, orientasi mobilitas, (b) Tunarungu: Bina Bicara, Bina Persepsi Bunyi dan Irama, (c) Tunagrahita: Binadiri, Sensomotor, (d) Tunadaksa : Bina gerak, sensomotor, Behaviour Terapi, (e) Umum: Play terapi, Music Terapi, Physioterapi, Hidroterapi, dan Occupational terapi.

\section{Blind Corner di Arsip dan Perpustakaan Daerah (Arpusda)}

Blind Corner bagi difabel merupakan layanan baru setelah menjalankan kegiatan Bank Buku 2010. Sebagai sasaran bukan hanya tunanetra di Kota Yogyakarta tetapi untuk siapa saja yang membutuhkan. Pelayanan Blind Corner adalah berbasis IT yang menyediakan 1 perangkat komputer yang menggunakan software JAWS. Dengan aplikasi ini komputer membacakan setiap teks yang tertera di layar PC sehingga dapat disimak pengunjung tunanetra. Perpusda juga telah melengkapi dengan koleksi buku elektronik diantaranya novel-novel Indonesia terkenal, buku bicara digital, file digital sehingga tunanetra dapat membaca buku umum melalui proses scanning dan pemanfaatan program JAWS. Juga disediakan pendamping untuk membantu pengunjung tunanetra dalam mencari buku sampai dengan pemanfaatannya.

Kepala Kantor Arpusda Kota Yogyakarta, Dra. Sri Sulastri mengungkapkan bahwa setiap orang seharusnya memiliki kesempatan yang sama untuk dapat menuntut ilmu. Para tuna netra tidak dapat melihat tetapi lebih peka bisa menggunakan indera lainnya untuk berinteraksi dengan lingkungan. Atas dasar itulah Arpusda berupaya mengakomodasi kebutuhan para difabel dengan menyediakan perangkat komputer yang adaptif. Layanan ini diharapkan dapat memenuhi kebutuhan tunanetra akan aksesibilitas informasi sebagai upaya menuju perpustakaan inklusif yang melayani seluruh lapisan masyarakat tanpa kecuali.

Sementara itu, sarana dan prasarana bangunan dan gedung pada lingkungan Dinas Pendidikan Kota Yogyakarta terutama bangunan sekolah belum memberikan kemudahan bagi difabel secara maksimal. Sarana prasarana bangunan sekolah memang disesuaikan dengan kebutuhan masin- masing sekolah, seperti yang terdapat di Sekolah Dasar Negeri (SDN) Giwangan dan Sekolah Menengah Pertama Negeri (SMPN) 15, yang termasuk sebagai sekolah penyelenggara pendidikan inklusi, sudah terdapat lantai landai yang dilengkapi dengan 
pegangan besi untuk tuna daksa dan lantai yang timbul untuk tuna netra. Peralatan penunjang untuk belajar siswa juga tersedia, seperti globe timbul dan huruf braille. Pada dua sekolah inklusi tersebut tersedia juga pengajar yang terdiri dari guru biasa dan guru pendamping khusus yang bertugas mendampingi para difabel yang menuntut ilmu di sekolah tersebut. Namun jumlah dari guru pendamping khusus belum memadai. Sementara itu, dana untuk penyediaan sarana dan prasarana bagi anak berkebutuhan khusus adalah hanya sebesar $2 \%$ dari total dana pendidikan Kota Yogyakarta.

\section{Pelayanan Sosial dan Ketenagakerjaan}

\section{Rehabilitasi dan Pelayanan Sosial}

Ada beberapa kegiatan rehabilitasi dan pelayanan sosial yang dilakukan. Pertama, kursus sulam. Kursus ketrampilan menyulam diikuti oleh 15 orang difabel. Dalam program ini dinas sosial menjalin kemitraan dengan SMKN 4 Nitikan dan Forum Komunikasi Keluarga Dengan Anak Kecacatan (FKADK). Pendampingan dilakukan oleh Dinas Sosial selama 1 tahun sampai didapatkan adanya kesepakatan antara difabel dan FKADK. Dimana kesepakatan ini berisi upaya untuk membentuk usaha berbasis kelompok. Selama ini yang sudah terbentuk adalah usaha produksi payet yaitu pada tahun 2011. Dana diperoleh atas pengajuan dari dinas sosial dan FKADK kepada Kementrian Sosial. Dana yang dialokasikanuntuk pengembangan usaha tersebut adalah sejumlah 3 juta/kelompok usaha.

Kedua, Program Pemberdayaan Keluarga Difabel. Program pemberdayaan ini berupa pemberian bantuan stimulan usaha dalam bentuk uang tunai dengan jumlah 1 juta per keluarga. Bantuan ini dapat diperoleh ketika keluarga difabel mengajukan proposal bantuan dana kepada FKADK dan dinas sosial. Selanjutnya untuk menetukan kelayakan penerima bantuan, dinas sosial melakukan verifikasi oleh tim survei dengan melakukan studi kelayakan atau kunjungan ke rumah-rumah keluarga pemohon bantuan untuk memastikan kelayakan pemberian bantuan. Pada tahun 2012 ini terdapat 20 keluarga difabel di Kota Yogyakarta yang menerima bantuan tersebut. Setelah proses verifikasi dan penentuan keluarga penerima bantuan, dinas sosial, FKADK dan keluarga penerima membuat kesepakatan tentang penggunaan uang bantuan tersebut. Setiap keluarga difabel penerima bantuan akan mendapatkan pengawasan dan pendampingan dari kelompok pendamping yaitu dinas sosial. Dalam penggunaan dana bantuan tersebut ditegakkan asas transparansi yaitu dengan adanya laporan penggunaan dana usaha kreatif.

Ketiga, Program bantuan pemberian alat bantu bagi kaum difabel. Alat bantu yang diberikan berupa kursi roda, kaki palsu, tongkat, alat bantu dengar, dsb. Dalam pemberian alat bantu ini, dinas sosial bekerjasama dengan YAKUM dan dokter Harso dari Solo. Pada tahun 
2012 Dinas Sosial menerima 18 proposal pengajuan bantuan alat bantu, namun yang dapat direalisasikan hanya 16 proposal. Dalam memberikan alat bantu ini, dinas sosial melakukan proses seleksi dan kelayakan sebagaimana penentuan bantuan bagi keluarga difabel. Pengajan proposal dilakukan oleh keluarga difabel dengan bantuan IKPSM (Ikatan Keluarga Pekerja Sosial Masyarakat). Untuk selanjutnya IKPSM menyerahkan proposal kepada dinas sosial untuk dilakukan proses seleksi.

Keempat, Program santunan jaminan hidup dari Kementerian Sosial. Pada tahun 2012 ini tercatat 33 keluarga difabel telah mendapatkan santunan jaminan hidup berupa dana dan kelima, Kegiatan Pemberdayaan Tenaga Kerja Penca (Difabel). Dalam rangka pembinaan tenaga kerja Aksus (Angkatan Kerja Khusus) dimana didalamnya termasuk tenaga kerja penca (Difabel), Dinas Tenaga Kerja dan Transmigrasi Provinsi Daerah Istimewa Yogyakarta menyelenggarakan Kegiatan Pemberdayaan Tenaga Kerja Penca (Difabel) Tahun 2012, yang pelaksanaannya dari dana APBN.Kegiatan Pemberdayaan Tenaga Kerja Penca (Difabel) Tahun 2012 ini telah dilaksanakan pada tanggal 9 s/d 14 April 2012 di Hotel Pangeran Emas yang beralamat di J1. Sisingamangaraja No. 95, Yogyakarta.

Kegiatan ini diikuti oleh 20 orang penyandang cacat (Difabel), yang keseluruhannya merupakan penyandang cacat fisik (tuna daksa). Dari 20 peserta tersebut,1 orang berasal dari Kota Yogyakarta, 11 orang dari Kabupaten Bantul, 7 orang dari Kabupaten Sleman, dan 1 orang dari Kabupaten Kulon Progo. Selama mengikuti kegiatan ini, peserta memperoleh bekal pengetahuan kewirausahaan dan bantuan sarana usaha, yaitu 10 orang usaha warung kelontong dan 10 orang usaha pengolahan makanan kecil.

Materi yang diberikan kepada peserta antara lain: Motivasi Usaha, Pengelolaan Usaha Kelontong, Cara Menentukan Jenis Usaha, Pengelolaan Usaha Makanan Kecil, Strategi Pemasaran, Manajemen Produksi, Pengelolaan Ekonomi Rumah Tangga, Pembukuan Praktis Usaha Kecil, Kalkulasi Usaha, Mengenal Lembaga Keuangan, dan Pembuatan Proposal Usaha. Narasumber-narasumber pada kegiatan ini berasal dari Dinas Sosial dan Tenaga Kerja (Disnakertrans) Propinsi Daerah Istimewa Yogyakarta, Ardhana, SMEDC UGM, Komunitas Hijau,SMKN 4 Yogyakarta dan praktisi pengusaha yang menyampaikan Success Story. Selain memperoleh materi di dalam kelas, para peserta juga mengikuti Praktek Kerja Lapangan (PKL) pada Toko Usaha Pertanian di daerah Gentan, Jalan Kaliurang, milik Bapak Ir. Marjoko yang sebelumnya juga memberikan materi kepada para peserta. Selain PKL di Toko Usaha Pertanian, para peserta juga diberikan pelatihan praktek pengolahan makanan kecil, dengan instruktur dari SMKN 4 Yogyakarta. Setelah mengikuti pelatihan, peserta memperoleh pengetahuan kewirausahaan, baik teori maupun praktek, dengan harapan termotivasi untuk 
menjadi wirausaha mandiri yang pada akhirnya dapat memperluas lapangan pekerjaan bagi orang lain pada umumnya dan difabel pada khususnya.

\section{Pengembangan dan Penyaluran Kerja}

Dalam bidang pengembangan tenaga kerja ini, Dinas Sosial membantu dalam menyalurkan kaum difabel dalam mencari kerja. Dalam Undang - undang dan Peraturan Pemerintah, termasuk Perda No 4 tahun 2012 tentang Perlindungan Dan Pemenuhan Hak-Hak Penyandang Disabilitas disebutkan bahwa perusahaan yang mempunyai 100 pekerja, maka harus memasukkan 1 ( satu ) kaum difabel untuk dipekerjakan pada perusahaan tersebut. Namun perusahaan juga mempunyai kriteria dalam memasukkan kaum difabel tersebut dan ini bersifat tidak memaksa.

Dinas Sosial memberikan penghargaan kepada perusahaan yang menempatkan kaum difabel di perusahaannya dalam bentuk pemberian gaji sebesar $25 \%$ dari gaji yang diberikan oleh perusahaan tersebut selama 1 ( satu ) tahun dan memberikan jaminan Jamsostek.

Pada tahun 2009, ada sebanyak 60 orang difabel yang disalurkan oleh dinas sosial kepada perusahaan. Salah satunya adalah perusahaan jahit di daerah Kota Gede yang kebetulan pemilik dari perusahaan tersebut juga kaum difabel. Selain penyaluran tenaga kerja, Dinas Sosial dan Ketenagakerjaan memberikan serangkaian pelatihan kepada difabel, meliputi: (a) Pelatihan kerja, (b) Pelatihan Tenaga Kerja Mandiri, dan (c) Pelatihan Teknis (contohnya : bordir dan jahit).

Dari jenis pelatihan yang diberikan kepada difabel, tampaknya program-program yang ditawarkan telah tidak lagi mampu menjawab kebutuhan difabel akan keterampilan praktis siap kerja. Disamping frequensi pelatihannya yang masih minim, jenis pelatihan yang ditawarkan juga telah tidak lagi mengikuti kebutuhan dunia kerja. Di saat dunia kerja sudah merambah generasi multi media dan computer, pelatihan-pelatihan bagi difabel masih berhenti pada menjahit, pertukangan dan sablon. Pada akhirnya, lulusannya hanyalah kembali menjadi buruh yang tidak lagi up to date dengan keterampilan-keterampilan yang dibutuhkan oleh pasar kerja. Belum lagi jika melihat testimony beberapa difabel yang merasakan dan mengetahui persis bagaimana pelatihan-pelatihan semacam itu diselenggarakan hanya sebagai proyek pemerintah semata. Hal tersebut menunjukkan bahwa difabel, sejauh ini masih ditempatkan sebatas obyek, dan bukan subyek yang mengetahui permasalahan dan kebutuhan mereka.

\section{Pelayanan Kesehatan}

Kesehatan merupakan hak dasar warga negara. Artinya, dalam kondisi dimana seorang warga negara tidak mampu mengupayakannya, maka sudah menjadi kewajiban negara untuk memenuhinya. Sebuah langkah maju adalah bahwa pada saat sekarang ini, telah ada beberapa 
skema jaminan kesehatan yang diselenggarakan untuk rakyat seperti JAMKESMAS, JAMKESSOS dan JAMKESDA. Namun, dari pengalaman yang dirasakan oleh difabel, jaminan-jaminan kesehatan tersebut ternyata tidak mampu menjawab kebutuhan kesehatan difabel. Salah satu masalahnya adalah terbatasnya item-item obat dan treatment yang ditanggung, sementara penyakit yang melanda tidak pernah mau peduli apakah yang menyandangnya orang miskin atau kaya.

Meski di Indonesia khususnya Kota Yogyakarta belum ada suatu penelitian mengenai tingkat kerawanan kesehatan bagi difabel, namun diyakini bahwa pada tingkat difabilitas tertentu, tingkat kerawanannya akan jauh lebih tinggi dibanding yang non difabel. Misalnya bagi difabel dengan paraplegi, setiap bulannya mereka membutuhkan perawatan kesehatan dan biaya-biaya medis yang tidak bisa ditangguhkan. Artinya, jika dengan penghasilan yang menurut kategori yang saat ini berlaku, mereka tidak dikategorikan sebagai masyarakat miskin, tetapi setelah dikurangi dengan biaya-biaya kesehatan yang rutin harus mereka keluarkan, bisa jadi penghasilan mereka tidak lagi cukup untuk memenuhi kebutuhan hidup lainnya.

Melihat permasalahan di atas, jelas bahwa jaminan kesehatan yang sudah ada belum dirasa mampu menjawab kebutuhan difabel akan jaminan kesehatan, dan untuk itu, perlu dikembangkan sebuah mekanisme jaminan kesehatan yang sensitive difabel dan mampu menjawab kebutuhan rakyat akan jaminan kesehatan.

\section{Aksesibilitas Perhubungan}

\section{Transjogja}

Sebagai sarana transportasi umum yang terbilang murah dan menjangkau seluruh bagian kota jogja, kehadiran Transjogja dengan segala kenyamanannya disambut hangat oleh masyarakat Yogyakarta secara umum, termasuk para difabel. Apalagi Transjogja dijanjikan dapat diakses oleh semua masyarakat dan juga menyediakan sarana sarana penunjang agar dapat ikut andil dalam transportasi masyarakat difabel. Beberapa hal yang telah dilakukan adalah menyediakan kursi yang dapat lipat di setiap bus Transjogja dan pembangunan halte bus Transjogja yang ramah difabel. Akan tetapi, upaya pelayanan tersebut ternyata dalam prakteknya tidak selalu memberikan kemudahan bagi difabel.

Beberapa hal tetap saja kurang memperhatikan keberadaan para difabel sebagai konsumen. Difabel masih mengalami kesulitan dalam mengaksesnbus kota terutama bagi difabel pengguna kursi roda. Beberapa hambatan bagi difabel dalam penggunaan Transjogja adalah adanya space yang terlalu lebar antara halte dan bis yang berhenti, ramp yang ada sering berbatasan langsung dengan tiang bendera, taman, pohon, dan benda benda lain tanpa ada space 
bagi kursi roda, dan perbedaan ketinggian dimana umumnya halte lebih tinggi $20-30 \mathrm{~cm}$ dibanding pintu bis.

Space yang terlalu lebar antara halte dan bis yang berhenti menyulitkan difabel baik tunanetra, pengguna kursi roda, maupun penderita semi ambulant (gangguan berjalan tapi tanpa menggunakan kursi Roda) naik maupun keluar bis. Ramp dipintu keluar terlalu curam. Bahkan hampir mencapai 45 derajat. Hal ini tentunya akan menyulitkan bagi difabel berkursi roda maupun pihak keluarga yang mendorong kursi roda tersebut. Padahal berdasarkan standar fasilitas difabel ideal ramp mestinya mempunyai ukuran 1:12 hingga 1:15 antara tinggi dan alasnya.

Ramp yang ada sering berbatasan langsung dengan tiang bendera, taman, pohon, dan benda benda lain tanpa ada space bagi kursi roda hingga menyulitkan difabel naik maupun turun dari halte.Adanya perbedaan ketinggian yang cukup besar antara jalan dan halte transjogja tanpa adanya ramp yang membatasi.

Perbedaan ketinggian dimana umumnya halte lebih tinggi $20-30 \mathrm{~cm}$ dibanding pintu bis menyulitkan difabel keluar dari bis.Beberapa hal tersebut mungkin terlihat cukup sepele bagi masyarakat secara umum, akan tetapi bagi difabel terutama pengguna kursi roda hal hal kecil tersebut sangatlah menyulitkan mereka. Padahal dalam pasal 5 Standard Rules on the Equalization of Opportunities for Persons with Disabilities 1993 menjelaskan bahwa Negara menjamin aksesibilitas difabel di Negara setempat dan pada 9 Desember 1975, PBB mendeklarasikan Hak-Hak Penyandang Cacat melalui resolusi no. 3447(XXX) untuk meningkatkan kualitas hidup kaum difable yang harus diikuti oleh seluruh negara anggotanya. Resolusi ini menjamin persamaan hak sebagai warga negara tanpa melihat kecacatan, menjamin hak untuk bekerja secara produktif dan berpartisipasi dalam kehidupan sosial serta pelarangan perlakuan diskriminatif dan kekerasan terhadap kaum difabel.

Dalam menyikapi masalah masalah tersebut PT Jogja Tugu Trans mulai melakukan pembenahan dari segi desain dan posisi lahan yang digunakan sebagai halte trans. Beberapa perbaikan yang mulai dilakukan penyedia Transjogja adalah; (a) Halte didisain lebih menjorok di pintu keluar menuju bis bertujuan agar mempermudah difabel keluar masuk bis, (b) Ram yang tidak terlalu curam. Hal ini diharapkan mampu meringankan beban dalam mendorong kursi roda para difabel. Dalam hal ini kemiringan ram ideal sudah dapat dilihat pada halte Jl. KH Ahmad Dahlan, (c) Halte hendaknya dibangun dan menyisakan space lebih kurang $2 \mathrm{~m}$ di sebelah kanan dan sebelah kiri ram agar ketika turun difabel tidak langsung berhadapan dengan taman, tiang bendera, dan tiang listrik sebagaimana pada halte Transjogja Jl. KH Ahmad Dahlan, Gembiraloka, Jl. Brigjen Katamso, (d) Penyediaan ram di batas antara jalan raya dan 
trotoar yang ada diatasnya, dan (e) Pintu halte dibangun sama tinggi dengan pintu bis dengan lebih teliti.

\section{Terminal Giwangan}

Selain Transjogja, Giwangan sebagai terminal terbesar Yogyakarta sendiri harusnya dibangun ramah difabel mengingat kevitalan sarana ini dalam menunjang kehidupan masyarakat. Sedangkan prakteknya terminal ini tidak mempunyai fasilitas yang baik bagi difabel selain sepasang ramp dengan kemiringan yang sudah memadai 1:12 tanpa ada fasilitas yang lain.

Menurut keterangan bagian informasi terminal tersebut difabel yang ada khususnya tunadaksa biasanya hanya digendong pihak keluarga di terminal tersebut karena memang minimnya fasilitas bagi difabel. Apalagi banyaknya jenjang tinggi ke lantai dua di terminal tersebut tanpa dilengkapi ramp alternatif. Hal ini seolah membuktikan bahwa kemudahan transportasi hanya milik kaum 'normal'.

Selain itu, toilet yang ada di tempat tersebut terbilang belum ramah difabel. Dengan lebar pintu masuk lebih kurang lima puluh sentimeter, kursi roda tentunya tidak akan dapat memasuki pintu tersebut. Selain itu, WC jongkok tanpa adanya pegangan (railing) biasanya juga menyusahkan bagi para difabel. Hal ini sangat kontras jika dibandingkan dengan toilet ramah difabel yang sudah disediakan di pusat pusat perbelanjaan dengan disain ramah difabel yang sudah dikembangkan di Jakarta.

\section{Stasiun Tugu}

Stasiun Tugu sebagai stasiun terbesar di Daerah Istimewa Yogyakarta pun belum memberikan akses kemudahan bagi difabel. Pada pintu masuk utama, difabel pengguna kursi roda mengalami kesulitan untuk masuk area stasiun karena harus menaiki tangga, tanpa ada jalan landai. Beberapa waktu yang lalu, seorang penyandang difabel mengadukan PT KAI khususnya Stasiun Tugu kepada Ombudsman Republik Indonesia (ORI) karena kurang menyediakan fasilitas yang ramah difabel. Menurutnya PT KAI belum mengakomodasi permintaan pelayanan non fisik bagi kaum difabel. Misalnya adalah arahan menuju loket bagi difabel. Petugas khusus pun menurutnya belum ada. Namun demikian, beberapa fasilitas umum seperti toilet telah memberikan kemudahan bagi difabel dengan penyediaan toilet khusus bagi difabel.

\section{Sepeda Motor Bagi Difabel}

Kepolisian Daerah DIY mengeluarkan Surat Nomor B/4965/XII/2008/Ditlantas ditujukan kepada Kepala Poltabes/Kepala Polres se-DIY perihal Pembuatan Surat Izin Mengemudi untuk Penyandang Cacat pada10 Desember 2008 lalu. Ada tiga hal pokok yang 
harus dilaksanakan oleh Poltabes/Polres: (a) Tidak ada diskriminasi dalam pengurusan SIM antara difabel dan nondifabel, (b) Memberikan pelayanan dan menyediakan sarana dan prasarana bagi difabel yang dapat mempermudah difabel mengurus SIM, (c) Difabel diperbolehkan melakukan modifikasi kendaraan bermotor dengan berpedoman pada ketentuan yang ada. Peraturan ini memang baru berlaku di kota Yogyakarta. Sedangkan di kota besar lain seperti Jakarta dan Semarang peraturan ini memanglah belum diterapkan.

\section{Marka Rambu}

Saat ini salah satu marka rambu yang disediakan oleh Dinas Perhubungan untuk difabel adalah di daerah Malioboro. Jadi marka rambu digunakan untuk penyeberangan kaum difabel yaitu dengan memencet tombol yang ada pada samping marka tersebut.

\section{Aksesibilitas Bangunan dan Fasilitas Umum}

Selama ini kaum difabel masih mengalami kesulitan dalam mengakses bangunan dan prasarana fisik yang ada di Kota Yogyakarta. Sebagai contoh, ketika memasuki Komplek Kantor Pemerintah Kota Yogyakarta, bagian Hubungan Masyarakat misalnya, para difabel berkursi roda tampak kesulitan ketika harus menaiki tangga tanpa ada jalur khusus kursi roda. Hal seperti ini masih sangat sering dijumpai di hampir semua bangunan perkantoran pemerintah dan swasta. Pihak-pihak yang berwenang melakukan pembangunan prasarana gedung belum banyak mempertimbangkan kemudahan akses bagi difabel. Hanya pada sejumlah kecil fasilitas publik, seperti Hotel Quality dan Puskesmas II Umbulharjo Kota Yogyakarta, telah aksesibel bagi kaum difabel dengan tersedianya jalan landai sebagai jalur khusus bagi pengguna kursi roda serta toilet khusus difabel.

Pada beberapa fasilitas publik yang ada di Kota Yogyakarta, Dinas Permukiman dan Prasarana Wilayah telah membuat dan membangun fasilitas umum yang ramah difabel yaitu jalan khusus atau trotoar bagi difabel di beberapa ruas jalan utama Kota Yogyakarta khususnya Jalan Malioboro. Pengerjaan penambahan blok khusus dilakukan di Jalan Taman Siswa, lingkar stadion Kridosono, Jalan Supomo, Jalan Diponegoro, dan di Titik Nol Kilometer Yogyakarta. Menurut Kepala Dinas Kimpraswil Kota Yogyakarta, Toto Suroto, di ruas jalanjalan tersebut, sebelumnya masih sering dipergunakan untuk berjualan dan parkir kendaraan bermotor.

Lajur blok penanda sebagai tanda jalan difabel diberi warna kuning. Lajur berada di bagian tengah trotoar dengan desain berbeda memiliki tanda menonjol pada permukaan jalan. Tanda tersebut merupakan standar penanda jalan khususnya tunanetra dan penyandang low vision. 
Namun demikian saat ini, jalan khusus atau trotoar tersebut telah banyak beralih fungsi menjadi lahan parkir atau bahkan sebagai tempat berjualan para pedagang kaki lima khususnya di Jalan Malioboro. Tindakan dari Dinas Kimpraswil adalah pada tahun ini telah menata ulang trotoar dan mengupayakan penyediaan trotoar yang baru serta melakukan pencegahan dan pengawasan untuk keteralihan fungsi menjadi lahan parkir juga dilakukan. Upaya yang dilakukan adalah dengan meninggikan jalur supaya tidak mudah dialihkan sebagai lahan parkir kendaraan bermotor. Selain itu, Dinas Kimpraswil juga memberikan persyaratan bagi para pengembang perkantoran dan pusat perbelanjaan untuk menyediakan jalan khusus/jalan landai dan toilet khusus difabel sebagai bentuk kemudahan aksesibilitas difabel terhadap prasarana fisik di Kota Yogyakarta.

\section{Kesimpulan dan Saran}

\section{Kesimpulan}

Sejumlah program dan pembangunan telah dilaksanakan oleh Pemerintah Kota Yogyakarta dalam penyediaan pelayanan pendidikan, perhubungan, sosial dan ketenagakerjaan. Beberapa pelayanan tersebut meliputi: pertama, pelayanan pendidikan (pendidikan inklusi, sekolah luar biasa, dan blind corner di Arpusda). Kedua, pelayanan sosial dan ketenagakerjaan yang terdiri dari rehabilitasi dan pelayanan sosial (Kursus sulam, Program Pemberdayaan Keluarga Difabel, Program bantuan pemberian alat bantu bagi kaum difabel, Program santunan jaminan hidup dari Kementerian Sosial, dan Kegiatan Pemberdayaan Tenaga Kerja Difabel), dan pengembangan dan penyaluran kerja. Ketiga, Aksesibilitas perhubungan: bis Transjogja, terminal Giwangan, Stasiun Tugu, sepeda motor bagi difabel dan marka rambu. Keempat, Aksesibilitas bangunan dan fasilitas umum: pembuatan trotoar khusus difabel dan fasilitas umum ramah difabel seperti jalan landai dan toilet khusus di pusat perbelanjaan dan perkantoran. Sedangkan untuk pelayanan kesehatan, pelayanan yang ada seperti JAMKESMAS, JAMKESSOS dan JAMKESDA belum memenuhi seluruh kebutuhan penyandang disabilitas.

\section{Saran}

Difabel juga adalah bagian masyarakat yang berhak akan pelayanan publik yang memadai. Selama ini pelayanan yang diberikan kepada mereka kurang setara dengan yang diperuntukkan bagi non-difabel. Oleh karena itu, sejumlah saran dikemukakan agar masyarakat berkebutuhan khusus (difabel) mampu eksis dan berkembang dalam kehidupan bermasyarakat. Pertama, peningkatan anggaran yang dikhususkan untuk pemenuhan hak-hak difabel. Kedua, sosialisasi kepada masyarakat bahwa difabel adalah membutuhkan pendampingan dan pelayanan yang setara dengan non-difabel. Sikap yang diharapkan adalah penerimaan secara 
wajar dan meniadakan diskriminasi serta stigmasasi. Ketiga, peran serta aktif seluruh stakeholders dalam pemberian pelayanan bagi kaum difabel. Keempat, sistem pengawasan atau monitoring terhadap fasilitas umum agar tetap diperuntukkan seperti tujuan semula, misalnya trotoar khusus bagi difabel memang harus dipertahankan, jangan sampai diperuntukkan untuk kegiatan lain seperti parkir atau pedagang kaki lima. Kelima, sanksi yang tegas bagi pelanggar aturan pemerintah tentang difabel seperti termaktub dalam UU no 25 Tahun 2009 tentang Pelayanan Publik.

\section{Daftar Pustaka}

Atep Adya Barata. (2003). Dasar-dasar Pelayanan Prima. Gramedia: Jakarta.

Dwiyanto, Agus. (2008). Pelayanan Inklusif, makalah disampaikan pada diskusi terbatas Pusat Kajian Manajemen Pelayanan LAN RI di Hotel Sahira Bogor, 9-10 Oktober 2008.

Joshi, Anuradha and Mick Moore. (2003). Institutionalised Co-production: Unorthodox Public Service Delivery in Challenging Environments. The Institute of Development Studies. Brighton

Kiser, Larry L. \& Stephen L. Percy. (1980). The Concept of Coproduction and Its Implication for Public Service Delivery. Paper presented at the 1980 Annual Meetings of the American Society for Public Administration, on April 13-16. Indiana University Bloomington.

LAN. (2008). Kajian Pelayanan Untuk $M$ a s y a $r$ a $k$ a $t$ D e $n g$ a $n$ Kebutuhan Khusus. Jakarta; LAN RI.

Lembaga Administrasi Negara. (2003). Penyusunan Standar Pelayanan Publik. LAN. Jakarta. Leisher, Susannah Hopkins \& Stefan Nachuk. (2006). Making Services Work for the Poor: A Syinthesis of Nine Case Studies from Indonesia, (Online), (http://www.innovations.harvard.edu/).

Ma r z u k i. P e n y a n d a $n$ g Ca c a t Berdasarkan Klasifikasi International Classification of Functioning for Disability and Health, (Online), (http://www.scribd.com/doc/24613087/Penyandang-Cacat-, diunduh pada bulan Oktober 2012).

Moloeng, Lexy. (1990). Metode Penelitian Kualitatif, Bandung: Remaja Rosdakarya

Nawawi, Hadari. (1998). Metode Penelitian Bidang Sosial, Yogyakarta: Gadjah Mada University Press

Nawawi, Hadari dan Martini Hadari. (1995). Instrumen Penelitian Bidang Sosial, Yogyakarta: Gadjah Mada University Press

Nurcholis, Hanif. (2005). Teori dan Praktik Pemerintahan dan Otonomi Daerah. PT. Grasindo. Jakarta. 